University of Minnesota Morris Digital Well

University of Minnesota Morris Digital Well

English Publications

Faculty and Staff Scholarship

2016

\title{
The Rise and Legitimization of the American Biographical Novel
}

Michael Lackey

University of Minnesota Morris, lacke010@morris.umn.edu

Follow this and additional works at: https://digitalcommons.morris.umn.edu/eng_facpubs

Part of the Literature in English, North America Commons

\section{Recommended Citation}

Lackey, Michael. "The Rise and Legitimization of the American Biographical Novel." In The American Biographical Novel. New York and London: Bloomsbury Academic, 2016.

This Book Chapter is brought to you for free and open access by the Faculty and Staff Scholarship at University of Minnesota Morris Digital Well. It has been accepted for inclusion in English Publications by an authorized administrator of University of Minnesota Morris Digital Well. For more information, please contact skulann@morris.umn.edu. 


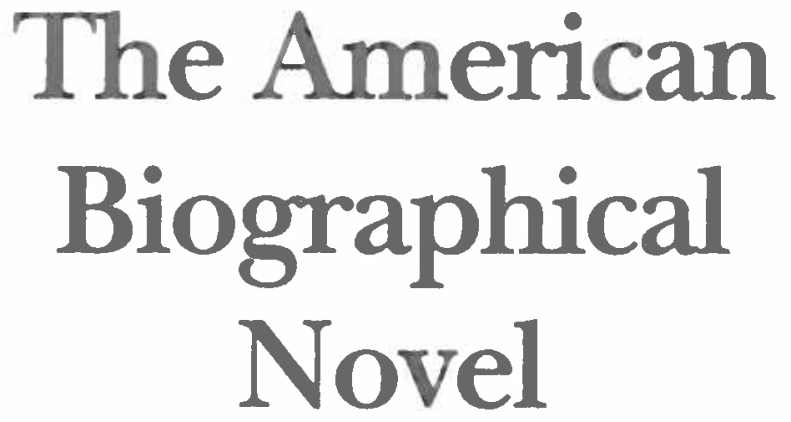

Michael Lackey

Bloomsbury Academic

An imprint of Bloomsbury Publishing Inc

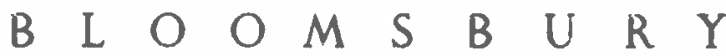
NEW YORK - LONDON - OXFORD - NEW DELHI - SYDNFY 
Bloometury Acsdomtc

An imprint of Bloomsbury Publishing inc

1385 Broadway
New York
NY 10018
USA

50 Bedford Square

London

WC1B 3DP

UK

unublocmenryeom

BLOOMSBUTY and the Diene logo ero tredomanke of Bloomsbury Publishing Ple

First published 2016

Michael Lackey, 2016

All rights reserved No part of this publication may be reproduced or transmitted in any form or by any means, electronic or mechanical, including photocopying, recording, or any information storage or retrieval system, without prior permission in writing from the publishers.

No responsibility for loss caused to any individual or organization acting on or refraining from action as a result of the material in this publication can be accepted by Bloomsbury or the author.

\section{Library af Congress Cetalogtng-topubllestion Data}

Names: Lackey, Michael, author.

Title: The American biographical novel / Michrel Lackey.

Description: New York: Bloomsbury Academic, 2016. | Includes bibliographical references and index.

Identifiers: LCCN 2015038230| ISBN 9781628926347 (hardback) | ISBN

9781628926330 (paperback)

Subjects: LCSH: Biographical fiction, American-History and criticism. I

Historical fiction, American-History and criticism. I Truth in

literature. | History in literature. | Politics in interature. |

Literature and history-United States-History-20th century. | Literature and society-United States-History-20th century. / BISAC. LITERARY

CRITICISM / American / General.

Classification: LCC PS374.B56 L32 2016 | DDC 813/08209-dc23

LC recoro available at hip:/Rcen.loc. gov/2015038230

$$
\begin{array}{r}
\text { ISBN: HB: } 978-1-6289-2634-7 \\
\text { PB: } 978-1-6289-2633-0 \\
\text { ePDF: } 978-1-6289-2636-1 \\
\text { OPub: } 978-1-6289-2635-4
\end{array}
$$

Typeset by Daanta Global Publishing Sernces, Chennai, India

Printed and bound in the Unitod States of America 


\section{CONTENTS}

Acknowledgments viii

1 The rise and legitimization of the American biographical novel 1

2 The fictional truth of the biographical novel: The case of Ludwig Wittgenstein 35

3 Surrealism, historical representation, and the biographical novel 83

4 Zora Neale Hurston and the art of political critique in the biblical biographical novel 127

5 Dual-temporal truths in the biographical novel 165

6 The biographical novel: A misappropriated life or a truthful fiction? 229

Bibliography 255

Index 269 


\section{The rise and legitimization of the American} biographical novel

The biographical novel's complicated journey to legitimization began in the 1930s, which is when the aesthetic form hadparadoxically-become popular and was roundly condemned. ${ }^{1}$ In 1937, Georg Lukács acknowledged "the popularity of the biographical form in the present-day historical novel." Works from the decade that immediately come to mind include Leonard Ehrlich's God's Angry Man (1932), Lion Feuchtwanger's Josephus Flavius novels (the first of which was published in 1932), Thomas Mann's Joseph novels (the first of which was published in 1933), Robert Graves' Claudius novels (the first of which was published in 1934), Irving Stone's Lust for Life (1934), Bruno Frank's A Man Called Cervantes (1934), Heinrich Mann's King Henry IV novels (the first of which was published in 1935), Arna Bontemps' Black Thunder (1936), Graves' Count Belisarius (1938), Stone's

\footnotetext{
'There were a few notable biographical novels before the 1930s, but these were so scattered and anomalous that they could not be characterized as part of a movement. For instance, Herman Melville published in 1854 Isreel Potter: His Fifty Years of Exile, and the Russian writer Dmitri Merezhkovsky authored a number of biographical novels in the late nineteenth and early twentieth centuries. From 1906 through 1908, Ford Madox Ford published The Fifth Queen trilogy, which examines the life of King Henry VIII's fifth wife. In 1929, C. Lenanton authored Miss Barrett's Elopement, the first of many biographical novels about Elizabeth Barrett Browning. 'Lukács (1983), The Historical Novel. Translated by Hannah and Stanley Mitchell. Lincoln and London: University of Nebraska Press, 300.
} 
Jack London, Sailor on Horseback (1938), Zora Neale Hurston's Moses, Man of the Mountain (1939), and Thomas Mann's Lotte in Weimar (1939). Based on this list, which consists of some notable works, it might seem that the biographical novel would have been officially recognized as a legitimate aesthetic form by the late thirties. But such is not the case.

In fact, Lukács devotes an entire section of The Historical Novel to a critical analysis clarifying precisely why the biographical novel is necessarily doomed to aesthetic failure. Lukács' critique is multifarious and intricate, so much so that I will return to it throughout this book. But for now, let me detail one of his most searing criticisms. For Lukács, the effective historical novel pictures the social, political, economic, and intellectual forces that created the great collisions of a particular age. Since the biographical novel centers the narrative in the life story of a single heroic figure, it necessarily distorts and misrepresents the historical reality, because "the character is inevitably exaggerated, made to stand on tiptoe, his historical calling unduly emphasized while the real objective causes and factors of the historical mission are inevitably omitted." ${ }^{3}$ This is not something that has just randomly happened within particular biographical novels. It is the inevitable consequence of the aesthetic form. Thus, Lukács concludes:

We may generalize this weakness of the biographical form of the novel by saying that the personal, the purely psychological and biographical acquire a disproportionate breadth, a false preponderance. As a result the great driving forces of history are neglected. They are presented in all too summary a fashion and relate only biographically to the person at the centre. And because of this false distribution of weights what should be the real centre of these novels - the given historical transformationcannot make itself felt sufficiently strongly. ${ }^{4}$

According to Lukács, there is something intrinsic to the literary form of the biographical novel that necessarily leads it to distort and misrepresent the historical and the political. Therefore, it is an irredeemable aesthetic form. 
Lukács' critique is the most focused and direct of the time, but there were other notable ones that led many to conclude that the biographical novel is either an impossible or illegitimate aesthetic form. For instance, without directly mentioning the biographical novel, Virginia Woolf, at roughly the same time (1939) as the publication of Lukács' book, makes it clear in her essay "The Art of Biography" why such an aesthetic form could not work, though her critique focuses less on history than on the impossibility of combining the actions distinctive to the creative writer and the traditional biographer. Lytton Strachey and the new biographers of the early twentieth century revolutionized the biography by making liberal use of the creative imagination and fictional techniques in depicting a person's life, thus giving the artist/biographer the "freedom to invent" something new, "a book that was not only a biography but also a work of art."s But ultimately, Woolf concludes, this "combination proved unworkable," because "fact and fiction refused to mix." As Woolf claims, the "novelist is free" to create, while "the biographer is tied" ${ }^{m}$ to facts. It should seem odd that Woolf would reject the biographical novel, because she published in 1928 the novel Orlando: A Biography. This work is important, because it challenged conventional genre distinctions. Critics have noted and Woolf has acknowledged that the novel is very loosely based on the life of Vita Sackville-West, and since the work is subtitled a biography, it has sometimes been characterized as an experimental biography that captures the spirit of her friend. ${ }^{8}$ But

"Woolf (1942), "The Art of Biography," in The Death of the Moth and Other Essays. London: The Hogarth Press, 123.

'Ibid. For useful discussions of Woolf's complicated approach to biography, see Ray Monk's "This Fictitious Life: Virginia Woolf on Biography and Reality" and Mark Hussey's "Woolf: After Lives"

Woolf (1942), 120.

'Elizabeth Cooley has written a very insightful essay that examines Woolf's engagement with and contribution to the innovative developments in biography of the 1920s and 1930s. However, her essay underscores the problem of an undefined terminology. The title of her essay is "Revolutionizing Biography: Orlando, Roger Fry, and the Tradition," which suggests that Orlando is a biography. Cooley creates additional confusion, because she refers to Orlando as a "biography" (71), "a novel" (75), and a "quasi-biographical novel" (71). But ultimately, she analyzes and assesses the work as a biography, which seeks to capture the "reality" of "Vita-Sackville West" (71). My claim is that Orlando is not an experimental biography that seeks to capture the reality of her friend. Rather, it is a novel that uses and radically alters the 
calling it a biography is problematic for two separate reasons. First and foremost, Woolf did not name the protagonist Vita. Second, the work is less focused on picturing accurately the life of the biographical subject, which would make it a biography, than on creating a story and character in order to project Woolf's vision, which makes it a novel. After all, instead of clarifying how the work strategically and accurately represents the life and person of Sackville-West, scholars tend to use Orlando to define Woolf's view of the fragmented or multiple self, the construction of gender and sex identity, the role of language in producing a subject, alternative conceptions of female subjectivity, an insightful critique of traditional biography, and pernicious forms of heteronormative coercion. So Orlando is a novel, because it gives readers Woolf's vision of life and the world rather than accurately representing a biographical subject, but it is not a biographical novel, because it does not name its protagonist after an actual historical person.

Flush is another work that scholars could wrongly consider a biographical novel. ${ }^{9}$ Published in 1933, this work is about Elizabeth Barrett Browning's dog, but there are two separate reasons why it

life of Sackville-West in order to examine the linguistic techniques of constructing character and structuring a life and to expose the limits and problems of biographical representation. The impulse and/or tendency to read Orlando alongside Roger Fry is a problem, because, as works belonging to separate and distinct genres, they seek to do incompatible things, which is something that Woolf acknowledges in a letter to Sackville-West. When discussing her work on the Roger Fry biography, Woolf says: "My God, how does one write Biography?" After confessing her puzzlement on this score, Woolf speculates if she should convert her book about Fry into fiction: "Or ought one, as I incline, to be purely fictitious?" (qtd. in Cooley, 79). For Woolf, there is an either/or choice. This is significant because, if she thought of Orlando as a biography, then she would know how to write one in 1939 when working on Roger Fry, since she would have already written one. Given that she admits that she does not know how to write a biography, it must be the case that she did not consider Orlando a biography. For Woolf, biography and fiction are separate and distinct, and as such, there need to be separate criteria for analyzing and assessing them.

"Marie-Luise Kohlke interprets Woolf's work as an "early comic biofiction," which re-focalizes "Barrett Browning's life through the eyes of her dog" (10). Julia Novak and Sandra Mayer have adopted this same approach in their essay "Disparate Images: Literary Heroism and the 'Work vs. Life' Topos in Biofictions about Victorian Authors." Both works use confusing terminology and fail to make a distinction berween 2 historical and a biographical novel. If the book had been titled Elizabeth Barrett Brouning as seen through the Eyes of her Dog Flush, then it would have been much closer to being a biographical novel. But given the work's focus on Flush as a historical-social type and Barrett Browning's subordinate 
does not qualify as a biographical novel. First, biographical novels are based on the lives of actual historical figures. While it is true that Barrett Browning had a dog named Flush, Woolf acknowledges in a postscript that her story is an invention and not based on an actual life: "It must be admitted that there are very few authorities for the foregoing biography." ${ }^{10}$ Given this fact, Flush actually fits more within the tradition of the historical rather than the biographical novel, because the effective historical novel foregrounds invented figures that embody "historical-social types." 11 For instance, Flush is an isolated dog who knows little about himself and other dogs. But after going for many walks, he discovers that there are various types of dogs and that he belongs to the canine aristocracy:

Flush knew before the summer had passed that there is no equality among dogs: there are high dogs and low dogs. Which, then, was he? No sooner had Flush got home than he examined himself in the looking-glass. Heaven be praised, he was a dog of birth and breeding! ${ }^{12}$

Creating the protagonist as a historical-social type enables Woolf to critique not the actual animal-figure or character Flush but the English aristocracy. On occasion, there are actual personages in historical novels, but these are peripheral figures that function to lend credibility to the portrait of the historical-social type and to place the created character within a specific spatial-temporal context. Barrett Browning is Woolf's actual personage, and she is certainly given a more prominent role than most actual figures within historical novels. But since the novel is titled Flush: A Biography and focuses mainly on its canine hero, it would be considered a comic and experimental variation of the historical novel rather than a legitimate biographical novel.

There is a clear reason why Woolf could not imagine her way to the biographical novel. In 1939, when Woolf published "The Art of Biography," she was writing a biography about her friend Roger Fry. Given all of her genre-bending and blending experiments, it

position within the work, it is a variation of the historical novel and not an example of a biographical novel.

10 Woolf (1933), Flush: A Biography. New York: Harcour, Brace, \& World, Inc., 171.

"Lukács (1983), 35.

${ }^{12}$ Woolf (1933), 40. 
would seem that she, more than anyone else, would have been able to use the occasion to author a biographical novel. But the strange fact is that Woolf could not imagine her way to the biographical novel, because she could not allow herself to take the liberty of altering facts about an actual person in order to convert him or her into a literary symbol. If she named her protagonist after an actual historical figure (Roger Fry), then she believed that she was bound to a specific truth contract, one that restricts the writer to the act of accurately representing the established facts. To be more specific, Woolf did not believe that she could make Fry into a woman midway through her biography in order to communicate something important about human subjectivity or sexual politics. Consciously and strategically inventing stories or altering established facts about the biographical subject in order to communicate a more substantive interior or cultural "truth" is not an option for Woolf in her biography of Fry. The only way she could justify doing so would be to change the biographical subject's name from, let us say, Roger to Orlando. Having changed the name, she could then take as many liberties as she wanted. To pur the matter simply, for Woolf, writers have to choose between the art of representing a person's life accurately, which would lead them to produce a biography, or creating a living and breathing character, which would lead them to produce a work of fiction. Blending the two in the form of the biographical novel is not an option.

It would seem that the biographical novel achieved some formal academic acceptance in February 1955, because in that year the American literary and cultural critic Carl Bode wrote a groundbreaking essay ("The Buxom Biographies") about it. But there are two separate reasons why this is not the case. Bode opens the essay by claiming that "in the last ten years prominent people have been doing their best to make an honest woman out of the biographical novel." Based on this comment, it would seem that Bode intends to offer a spirited defense of the genre, but he actually goes on to argue that the aesthetic form has not yet reached maturity: "The biographical novel still goes its bosomy way, its flimsy clothing tattered and torn in exactly the wrong places." Consequently, Bode concludes that "the biographical novel deserves more to be pitied than censured." 13

\footnotetext{
"Bode (1955), "The Buxom Biographies," College English 16(5): 26.5
} 
What makes Bode's article ultimately unfortunate is less his condemnation than his muddled understanding of the biographical novel. For Bode, if a biography is either bad or stylized, then it would qualify as a biographical novel. For instance, in charting what he considers the rise of the biographical novel, Bode does not begin with a discussion of books that strategically invent characters and scenes in relation to a factual historical figure. Rather, he begins with a brief analysis of Mason Weems's 1927 biography of George Washington. Here is his logic: because Weems took the liberty of including undocumented fables about Washington, his work is disqualified from being a biography and therefore becomes a novel. Bode's approach, however, is not always so negative. When discussing Carl Sandburg's biography of Abraham Lincoln, Bode suggests that Sandburg's "felicity of style" implicitly renders his "life of Lincoln" a biographical novel. ${ }^{14}$ Implicit in Bode's article are the two following assumptions: First, the biography gives readers "unadorned truth." 1 Second, what qualifies a work as a novel is the introduction of an embellished truth or "an orderly, almost a symphonic, structure and a literary richness of style." 16 According to this logic, if a biography contains an undocumented "truth" or is well written, then it would become a de facto biographical novel.

Stone was one of the most important figures in this story, as he used the phrase biographical novel as a subtitle for many of his works: Jack London, Sailor on Horseback: A Biographical Novel (1938); Immortal Wife: The Biographical Novel of Jessie Benton Fremont (1944); The Agony and the Ecstasy: A Biographical Novel of Michelangelo (1961); Those Who Love: A Biographical Novel of Abigail and John Adams (1965); The Greek Treasure: A Biographical Novel of Henry and Sophia Schliemann (1975); The Origin: A Biographical Novel of Charles Darwin (1980); and Depths of Glory: A Biographical Novel of Camille Pissarro (1985). Despite Stone's considerable success, he expresses much frustration with academics for not recognizing the legitimacy and value of the biographical novel. In a 1957 lecture at the Library of Congress, Stone confirms that Bode's essay, which he discusses at some length, did not lead to the legitimization of the biographical novel. In a

\footnotetext{
${ }^{1}$ Bode (1955), 268.

"Bode (1955), 266.

${ }^{16}$ Ibid.
} 
perceptive remark about the implicit prejudices against the aesthetic form, he queries: "I would like at this moment to interject, with less bitterness than puzzlement, I hope, the question of why the historical novel, with its accurate background but fictional characters, should have been more acceptable to the academicians than the biographical novel, which is accurate not only in background but in the people involved?"17 The reading public may be excited about the biographical novel, but, as Stone rightly notes, academics continue to treat it as a "bastard form." 18

One of the most important, contentious, and sophisticated debates about the biographical novel occurred in 1968, when the historian C. Vann Woodward moderated a forum with Robert Penn Warren, Ralph Ellison, and William Styron on the topic of "The Uses of History in Fiction." To start the debate, Woodward claims that there is a "distinction between the historian and the novelist." 19 Unlike the novelist, the historian cannot "invent characters, invent motives for his characters. ${ }^{20}$ But Warren rejects this assumption because he holds that the past is always mediated through a specific consciousness, which means that historians, whether they realize it or not, use the creative imagination as much as novelists in order to construct their "historical characters." Warren would clearly reject Bode's naive belief in the existence of "unadorned truth." Though Warren claims that historians and novelists are the same in that they use imagination to access and construct their subjects, he does make a distinction between the two. The fiction writer "claims to know the inside of his characters, the undocumentable inside," while the historian "wants to find the facts behind the world." 22 Like Warren, Ellison rejects the idea that there is a distinction between "American historiography and American fiction," for "they're both artificial," which is why Ellison refers to historians as "responsible liars." 23

\footnotetext{
"Stone (1957), "The Biographical Novel," in Three Views of the Novel by Irving Stone, John O'Hara and MacKinlay Kanton. Washington: The Library of Congress, 14.

"Stone (1957), 16.

"Ralph Ellison, William Styron, Robert Penn Warren, and C. Vann Woodward (Spring 1969), "The Uses of History in Fiction," Southern Literary Journal 1(2): 59. ${ }^{20}$ Ellison et al. (1969), 59.

"Ellison et al. (1969), 61.

${ }^{22}$ Ibid.

'Ellison et al. (1969), 62.
} 
Since Ellison considers history fiction, it might seem that he would favor the biographical novel. But such is not the case. At one point during the discussion, Ellison praises Warren for engaging history correctly in All the King's Men:

I think that Red Warren, who has always been concerned with history, has offered us an example of how to confront the problem of history as the novelist should. I think that when he wrote about a great American politician who governed his state and refused to intrude into the area of the historian, he refused because he was canny enough to realize that he could never get that particular man into fiction. And yet, I believe that he did use that man to bring into focus within his own mind many, many important facts about power, politics and class, and loyalty. ${ }^{24}$

Warren's decision not to name his character Huey Long was sound and astute, because he was able to articulate some crucial historical "truths" about the dynamics of power, the psychology of politics, and the structures of class. Had Warren ventured into the realm of the historian by specifically naming his character Huey Long, thus making All the King's Men a biographical novel, he would have failed to represent the complexity and details of the man and he would have made himself vulnerable to attack from historians.

While Ellison's comments are about Warren's work, they are also a not-so-subtle critique of Styron's 1967 biographical novel The Confessions of Nat Turner, which differs from All the King's Men because Styron named his character after the original historical figure. This novel caused considerable controversy for exactly the reasons Ellison mentions: people claimed that Styron misrepresented Nat Turner and made factual errors about him. For Ellison, when novelists encroach on the historians' intellectual terrain by writing a biographical novel, they make themselves vulnerable to critique: "The moment you put any known figures into the book, then somebody is going to say, 'But he didn't have that mole on that side of his face; it was on that side. You said that he had a wife; he didn't have a wife.'" 25 Therefore, instead of naming the main character

${ }^{24}$ Ellison et al. (1969), 64-S.

${ }^{25}$ Ellison et al. (1969), 74. 
after the original, as Styron does, Ellison counsels writers to "lie and disguise a historical figure, ${ }^{26}$ as Warren does.

As it happens, Ellison failed to understand the trajectory of contemporary literature, for the American biographical novel has now become a dominant literary form. Gore Vidal's Burr and Lincoln, Bruce Duffy's The World As I Found It (Ludwig Wittgenstein), Michael Cunningham's The Hours (Virginia Woolf), Russell Banks' Cloudsplitter (Owen Brown), and Joyce Carol Oates' Blonde (Marilyn Monroe) are just a stellar few that have received considerable praise from respected scholars and general readers. But what intellectual and aesthetic developments made this valorization of the biographical novel possible? I will provide numerous answers to this question in the following pages, but for now, I want to focus on postmodernism, which radically compromised the traditional literary symbol and led general readers to give authors more creative license in their representation of historical figures.

To clarify the nature of these developments, it would be useful to examine specifically how the committee for the Pulitzer Prize in fiction struggled to understand and ultimately came to accept the biographical novel. The first biographical novel to pose a serious challenge for the Pulitzer committee was Styron's The Confessions of Nat Turner. Significant is the fact that the committee did not yet have a suitable vocabulary or conceptual framework for making systematic sense of the biographical novel, which in part explains its difficulty in assessing it. The 1968 report notes that "the Fiction Jury could not reach a unanimous opinion" about this novel, so it submitted a form with "a minority and a majority opinion and a possible compromise selection. ${ }^{n 27}$ To come to terms with its own confusion, there is an extended discussion of Styron's novel. The report is six pages and consists of twenty-two paragraphs. Styron's novel is discussed in twelve of those paragraphs, and it is the exclusive subject of ten. The only other novel to come close is Isaac Bashevis Singer's The Manor, which is mentioned in six paragraphs and the primary subject of only two.

As important as the length and focus of the report are the comments about Styron's novel, which shed considerable light on

¿Ibid.

2Tischer and Fischer (2007), Chronicle of the Pulitzer Prizes for Fiction: Discussions, Decisions, Dissents. Munchen: K.G. Saur Verlag, 294. 
the committee's assumptions and expectations regarding fiction. Even though Lukács would have characterized and faulted The Confessions of Nat Turner as a biographical novel, both Styron and the committee saw it as a historical novel. This is clear from the decision of John $\mathrm{K}$. Hutchens, one of the committee members, to cite Styron, who says that The Confessions is "less an 'historical novel" than a meditation on history. ${ }^{n 28}$ lessening the degree to which The Confessions is a historical novel does not negate it as one. And it is worth noting that, when Styron defined and defended his novel during the forum with Ellison and Warren, he used Iukács' The Historical Novel to do so. What Hutchens admires so much about the work is Styron's ability to do two things simultaneously: to use rich, imaginative language in order to engage the reader and to represent the historical figure accurately. On the basis of these criteria, Hutchens concludes that Styron "has written what is, in my opinion, the finest American novel of 1967, and the one that promises to be most enduring as art and re-created history." 24

Maxwell Geismar and Melvin Maddocks were the two other readers, and they disagreed with Hutchens on both accounts. Their comments are useful, because they indicate what the members consider the freedoms a writer is allowed and not allowed to take with the historical record. Geismar and Maddocks claim that The Confessions is a flawed novel because there are "serious defects in the use of its historical material" as well as the "prose style." It might seem that these two problems are separate and distinct, but for these readers they are actually inextricably linked. Maddocks claims that the novel's "writing" is "too smooth, too "literary." 30 This is a problem because such literary language lacks verisimilitude. According to Geismar, instead of replicating the "early 19th century language" of Nat Turner or Thomas Gray, the lawyer who took the rebel slave's confession, "Styron has added a large percent of romantic Southern rhetoric to the point of making the novel's prose so fragrant, redolent, and prolix as to be overblown and luscious. ${ }^{.{ }^{3}}$ The literary expectation is this: for a historical novel to be effective and legitimate, the language must accurately reflect the way people

\footnotetext{
"Ibid.

${ }^{29}$ Fischer and Fischer (2007), 295.

orbid.

${ }^{3}$ Fischer and Fischer (2007), 297.
} 
spoke from the represented period. And if the language fails to do this, then the author must have a faulty understanding of the historical period.

Most prominent biographical novelists reject the Geismar/ Maddocks view. In their effort to represent a structure of consciousness or a political ideology, biographical novelists frequently subordinate empirical facts to a symbolic truth. For instance, when discussing the construction of her fictional characters, Oates told me in an interview that her "characters are more interesting, elastic and subtle than the real people." Indeed, she goes on to say that the actual historical figures are "not nearly as nuanced or subtle as my fictitious characters." 32 This is the case because Oates uses her characters to access and represent a larger political, psychological, and/or cultural truth. In their assessment of a literary work's engagement with history, Geismar and Maddocks acknowledge that novelists can use fiction to illuminate the historical record, but they forbid tampering with the literal facts, which explains why they drew a damning conclusion about The Confessions of Nat Turner: "While William Styron may have the right to 'invent' historical incidents within the framework of recorded history, he has in this book taken some dubious liberties with history itself." 33 For Geismar and Maddocks, Styron has the right to invent scenes within the context of an established historical frame, but he does not have a right to alter history itself. For Oates, however, altering history is precisely what the biographical novelist does.

So contra Geismar and Maddocks, biographical novelists unapologetically take "liberties with history itself." But what enables them to justify this is not so much a cynical rejection of historical truth as a subordination of a particular narrative truth. To illustrate, let me supply an example from Julia Alvarez's In the Time of the Butterflies, which is about the lives of the Mirabal sisters in the Dominican Republic during the reign of the dictator Rafael Trujillo, who frequently used young girls for his own personal satisfaction. Trujillo took a particular interest in Minerva Mirabal, who was repulsed by the older man's advances. At a formal party, Trujillo

\footnotetext{
${ }^{32}$ Oates (2014), "Enhanced Symbolic Interiors in the Biographical Novel," in Truthful Fictions: Conversations with American Biographical Novclists. Editor and Interviewer Michael Lackey. London and New York: Bloomsbury, 188.

${ }^{13}$ Fischer and Fischer (2007), 296.
} 
clearly made an indecent remark to Minerva, which prompted her, so the story goes, to slap him so hard that it left an imprint on his face. In my interview with Alvarez, she told me that the surviving Mirabal sister said that "there had been no slap. ${ }^{\text {"H }}$ It was just part of Dominican folklore. And yet, Alvarez decided to keep the slap in the novel. Why? Through the story of the Mirabal sisters, Alvarez could express some important political and psychological truths. Men in the late 1950s felt that they were entitled, that they could take all kinds of liberties with women. How could Alvarez best express the psychological rage that women felt about the political system that allowed men to violate women with psychological and legal impunity? The slap, while literally untrue, expresses a psychological truth that women experienced about the unjust political system in which they lived. Many biographical novelists agree on this principle: it is permissible to alter historical fact, so long as the writer remains faithful to more important symbolic truths. More specifically, a political truth about the psychic life of women in the 1950 s is more important than a literal truth about a slap.

So let me generalize at this point. Biographical novelists privilege symbolic representation over historical or biographical fact, because they think that a symbolic reality will give readers something more substantial about the nature of a historical period. In other words, they are different from historians and biographers in that they seek to create symbolic figures, while historians and biographers seek to represent factual "reality." With regard to Styron's novel, all three Pulitzer committee members did not yet have an epistemological or aesthetic framework that would enable them to understand or appreciate the biographical novel. Geismar and Maddocks failed to see how Styron's subordination of certain historical facts enabled him to symbolically access and represent more substantive historical structures and truths (I will define these "structures" and "truths" in Chapter 5). As for Hutchens, while he praises The Confessions, it is clear that he considers it a historical rather than a biographical novel.

It might seem that 1980 marks the official arrival of the American biographical novel, for it was in this year that Norman Mailer

\footnotetext{
${ }^{34}$ Alvarez (2014), "Fixed Facts and Creative Freedom in the Biographical Novel," in Truthful Fictions: Conversations with American Biographical Novelists. Editor and Interviewer Michael Lackey. London and New York: Bloomsbury, 31.
} 
received the Pulizzer Prize in fiction for The Executioner's Song, which chronicles the last nine months of Gary Mark Gilmore's life. But there are two separate reasons why this is not the case. First, by virtue of Mailer's own definition, The Executioner's Song would not qualify as a biographical novel. If, as Woolf claims, the art of representing a person accurately is the primary task of the biographer while the art of inventing scenes to create a living character is the primary task of the novelist, then Mailer's novel would qualify as a biography but not a novel. As Mailer claims in his a Afterword, The Executioner's Song is a "factual account," a "true life story." ${ }^{\text {"s }}$ The "novel" makes use of "interviews, documents, [and] records of court proceedings" to give readers "a factual account of the activities of Gary Gilmore," evidence about Gilmore, he chooses "the version that seemed most likely." ${ }^{37}$ Given the absence of overt creative invention, it is difficult to justify calling The Executioner's Song fiction.

An example from Bruce Duffy's work, which I will discuss in considerable detail in Chapter 2, will enable me to bring into sharp focus the distinction between The Executioner's Song and a biographical novel. Postmodernists argue that fictionalizing reality is inescapable because the art of framing a character or story necessitates a creative shaping of material. While most biographical novelists acknowledge the inevitable fictionalization inherent within all writing, they also do something more conscious and strategic. They invent stories that never occurred in order to answer perplexing questions, fill in cultural lacunae, signify human interiors, or picture cultural ideologies. For instance, Ludwig Wittgenstein had a conflicted sense of himself, for he was a Jew whose family became Catholic. In The World As I Found It, Duffy brilliantly dramatizes the famous biographical moment when Wittgenstein confesses to the philosopher G. E. Moore that he deceived him and others by concealing his Jewish heritage. Had Duffy only included scenes like Wittgenstein's confession, The World As I Found It would be an engaging biography and not a biographical novel. But to access and represent Wittgenstein's conflicted self, Duffy creates a scene much earlier in the novel with the Austrian philosopher in a Jewish

\footnotetext{
Mailes (1998), The Executioner's Song. New York: Vintage Books, 1053. Mailer (1998), 1051.

sTbid.
} 
theater, which features a play about the Jewish monster figure Yosele Golem, who is described as "a kind of beast." So captivated by the performance is Wittgenstein that "for five hard minutes he was the play, Yosele Golem." 13 During my interview with Duffy, he said that his Wittgenstein was "so upset by a seemingly garish scene and simple-minded scene-and so unconscious of his deeper emotions-that he passes out." This is the case because he was forced to confront in the theater "his true past, ${ }^{n 9}$ specifically his Jewish heritage. However, as Duffy went on to say, this scene never actually occurred. This is the kind of scene that does not appear in The Executioner's Song, which is why 1980 cannot be considered the official arrival year of the American biographical novel.

This lack of strategic and overt invention explains the 1980 Pulitzer committee's conflicted response to The Executioner's Song. The committee obviously recognized that there was a problem giving Mailer's work an award for fiction, for it tries to make the case for it as a novel in the first sentence of the report: "The Executioner's Song is subtitled 'A True Life Novel."m40 Something is not entirely right about this work, which is why the committee members feel the need to justify that it is actually a novel. Indeed, in its six-sentence report, the members strategically and repeatedly emphasize the way the novel expands "our conceptions of the limits of history and fiction" and "challenges our notions of fiction." The members obviously want to underscore how The Executioner's Song challenges our definitions of fiction so that they can justify their decision to give Mailer an award for fiction. This becomes most apparent when we look at the letter that the chairman of the committee, Frank McConnell, submitted to the advisory board. McConnell notes that one committee member, Anatole Broyard, "expressed some concern that Mailer's book may not really be a novel (whatever that means). ${ }^{042}$ McConnell obviously did not agree with that assessment, which is clear from his parenthetical

\footnotetext{
${ }^{31}$ Duffy (2010), The World As I Found It. New York: New York Review Books, 145. "Duffy (2014), "In the Fog of the Biographical Novel's History," in Truthful Fictions: Conversations with American Biographical Novelists. Editor and Interviewer Michael Lackey. London and New York: Btoomsbury, 12.5.

${ }^{40}$ Fischer and Fischer (2007), 349.

"Ibid.

${ }^{42}$ Fischer and Fischer (2007), 348.
} 
interjection. But Broyard was rightly "worried that giving the prize to" Mailer's book "may raise unpleasant controversy and embarrass the Pulitzer Committee, ${ }^{n 3}$ because, if it is correct to say that The Executioner's Song contains no overtly fictional characters or scenes, then it would be difficult to justify awarding it the Pulitzer Prize for fiction.

The second reason why 1980 does not mark the official arrival of the biographical novel is the committee's subtle bias against the genre. The report says: "And although the story told is about real people, and based upon a great mass of documentary material, The Executioner's Song is an extraordinarily ambitious and powerful narrative." Note the hint of surprise ("although") that a "novel" about a "real" person that uses "documentary material" could be a "powerful narrative." These are clearly people who have not yet read J. M. Coetzee's The Master of Petersburg, Colum McCann's Dancer, Anne Enright's The Pleasure of Eliza Lynch, Hilary Mantel's Wolf Hall, and Laurent Binet's $H H b H$. At this point, the literary establishment still needs to undergo a few more transformations before it could understand or appreciate the biographical novel.

In 1982, Ina Schabert published a very important and useful essay titled "Fictional Biography, Factual Biography, and their Contamination," which advanced our attitude toward biographical fiction. In addition to identifying numerous biographical novels, Schabert provides some useful frameworks for understanding scholarly efforts to define the aesthetic form and for distinguishing the biographical novel from biography. However, there is good reason to have some serious reservations about Schabert's work and approach. Her essay was published in the journal Biography, and so she defines and assesses the biographical novel as biography rather than fiction. Paul Murray Kendall, whose work Schabert discusses at some length, was the first major scholar to approach biographical fiction in this manner. In his 1965 book The Art of Biography, he refers to "the radical left" invention of "the novelas-biography," which, he contends, is "almost wholly imaginary." 4 For Kendall, the novel-as-biography is like the fictional biography in that it makes use of the "literary element" in the construction of

"Mbid.

${ }^{4}$ Fischer and Fischer (2007), 349.

"Kendall (1967), The Art of Biography. New York: The Norton Library, 126. 
a life, but it is different from fictional biography because novels-asbiography "imaginatively take the place of biography where there can be no genuine biography for lack of materials." ${ }^{40}$ Kendall's logic here is confusing. If novels-as-biography displace the biography, thus rendering them not biographies, then on what grounds can Kendall call them biographies (novels-as-biography) and critique them as a biography? The whole point is that they are not biographies. As such, standards for determining the quality of biography cannot and should not be applied to the biographical novel.

Kendall's work has had an extremely negative and lasting impact on scholarship about the biographical novel. There has been, fortunately, an explosion of interest in biography, autobiography, memoir, and life writing since the publication of Kendall's book. Unfortunately, this has led many scholars to define and assess biographical novels as biography. For instance, while Schabert references and has a positive approach to the "biographical novel," she interprets the genre through the lens of biography, which is obvious from the title of her 1990 book In Quest of the Other Person: Fiction as Biography. As Schabert claims, her project examines how fictional biographies and biographical fictions, terms that she unfortunately uses interchangeably, enable readers "to get knowledge of the real, other person." ${ }^{n 7}$ Since the publication of Schabert's book, scholars have been analyzing, interpreting, and assessing biofiction primarily in relation to the methods and objectives of biography. Let me cite just a few important studies to illustrate this point.

In his 1991 essay "Biofictions," Alain Buisine clarifies how postmodernism contributed to the making of the biographical novel, because it underscores the degree to which fiction necessarily plays a role in the construction of a biographical subject and why, therefore, an accurate representation of the biographical subject is ultimately impossible. For Buisine, these intellectual developments led to the rise of biofiction, which is a postmodern form of biography that implicitly concedes through its dramatization that it cannot accurately signify or represent the biographical subject because the author's subjective orientation will always

\footnotetext{
*Kendall (1967), 127.

${ }^{47}$ Schabert (1990), In Quest of the Other Person: Fiction as Biography. Tubingen: Francke Verlag. 1.
} 
inflect the representation. ${ }^{48}$ John Keener follows suit in his 2001 book Biography and the Postmodern Historical Novel, which examines the continuum of what he calls "biographical narrative." According to his model, "biographical fiction" is that which "applies 'novelistic' discourse to the representation of an historical life." $\$ 0$ While Monica Latham tries in 2012 to show how biofiction straddles the two worlds of fiction and biography, she ultimately defines biofiction in terms of the biographer's attempt to represent with as much "verisimilitude" as possible the biographical subject's "life story." Julia Novak and Sandra Mayer uncritically take this approach as a given when they claim in their recent article that biofiction is an effort to recover "the (historical) author's 'true' and 'authentic' self behind the mask of his/her renowned public persona." ${ }^{\text {s2 }}$ All these scholars define biofiction primarily in relation to the goals and techniques of biography.

But foregrounding the biographical is problematic because most authors of biofiction explicitly claim that they are not doing biography. As Ehrlich claims in the author's note to God's Angry Man, which was initially published in 1932: "This work is a novel, not a biography or a history." 53 Subsequent biographical novelists make an almost exact claim. For instance, in the foreword to Wife to Mr. Milton, Robert Graves says that "this book is a novel, not a biography "st; in the note to Death of the Fox, George Garrett says that "this is a work of fiction," and he goes on to claim that "it is nor supposed to be in any sense a biography of Sir Walter Ralegh"s5; and in the afterword to An Imaginary Life, David Malouf states that what he "wanted to write was neither historical

\footnotetext{
"Buisine (1991), "Biofictions," Revue des Sciences Humaines 224: 7-13.

*Keener (2001), Biography and the Postmodern Historical Novel. Lewiston: The Edwin Mellen Press, 1.

sokeener (2001), 183.

"Latham (Winter 2012), "Serv[ing] under two masters": Virginia Woolf's Afterlives in Contemporary Biofictions," a/b: Awto/Biography Studies 27(2): 355.

"2Novak and Meyer (2014), “Disparare Images: Literary Heroism and the 'Work vs. Life' Topos in Contemporary Biofictions about Victorian Authors," Neo-Victorian Studies 7(1): 25 .

"Ehrlich (1941), God's Angry Man. New York: The Press of the Readers Club, ix. sa Graves (1962), Wife to Mr. Milton: The Story of Marie Powell. New York: The Noonday Press, vii.

"Garrett (1971), Death of the Fox. New York: Doubleday \& Company, Inc., 9
} 
novel nor biography, but a fiction"s6 - Schabert refers to these last three novels as fictional biographies in both her article and book, but these authors would clearly reject the idea that their works are biographies. More recent biographical novelists are just as adamant in stating that their works are fiction, not biography. As Duffy says in the preface to The World As I Found It: "This is a work of fiction: it is not history, philosophy or biography." 57 On the copyright page of Blonde, Oates tells her reader explicitly that "Blonde should be read solely as a work of fiction, not as a biography of Marilyn Monroe." 58 In an interview, Banks characterizes his biographical novel about Owen Brown (Cloudsplitter) as something other than a biography: "It seemed to me a given that I could write from inside a historical figure. I could write a 'life' of that figure, using that figure's life, but I would be writing a dramatic narrative, a work with a dramatic shape and intent, rather than a biography of that character." 59 The biographical novel is, first and foremost, fiction, which is why Parini insists in the acknowledgments of The Passages of H.M. (Herman Melville) that "this is a novel, not a literary biography." 60

In the postscript to the biographical novel In the Time of the Butterflies, Alvarez clearly expresses why it is important to keep in mind that what she is writing is an experimental form of the novel and not an experimental form of the biography. For Alvarez, what readers get in her work "are not the Mirabal sisters of fact, or even the Mirabal sisters of legend." Alvarez makes this claim not because she wants to ward off criticism nor because she has a dismissive view of biography. Rather, she makes it because she wants to identify one of her limitations. As she says, she does not have "the talents and inclinations of a biographer to be able to adequately record" ${ }^{n 1}$ the lives of the Mirabal sisters. The biographer

\footnotetext{
"Malouf (1978), An Imaginary Life. New York: George Braziller, 153.

"Duffy (2010), The World As I Fourd It. New York: The New York Review of Books, "Preface."

"Oates (2009), Blonde. New York: The Ontario Review.

"Banks (2014), "The Truth Contract in the Biographical Novel," in Truthful Fictions: Conversations with American Biographical Novelists. Editor and Interviewer Michael Lackey. London and New York: Bloomsbury, 43-4.

60Parini (2010), The Passages of H.M.: A Novel of Herman Melville. New York: Anchor Books, 453.

"Alvarez (2010), In the Time of the Butterflies. Chapel Hill: Algonquin Books of Chapel Hill, 324.
} 
has talents, skills, and sensibilities that are different from those of a novelist. Alvarez is not a biographer, because she lacks those talents and sensibilities. Instead, she is a novelist, who uses fictional techniques to narrate a story, which just happens to be based on the lives of real people. Therefore, when people assess the quality of In the Time of the Butterflies, they should judge it as a novel and not a biography. Joanna Scott puts the matter best. Discussing her biographical novel Arrogance, which centers on the life of the Austrian artist Egon Schiele, Scott says: "I wasn't trying to pretend that my Schiele was the real Schiele. I just wanted him to be real." ${ }^{102}$ In other words, Scott wants to be judged for doing what she does, which is to create a real and memorable character in a novel and not to accurately represent the life of a real person.

What we get in a biographical novel, then, is the novelist's vision of life and the world, and not an accurate representation of an actual person's life. Put differently, biographical novelists differ from biographers, because, while authors of traditional and fictional biographies seek to represent the life (or a dimension of a life) of an actual historical figure as clearly and accurately as possible, biographical novelists forgo the desire to get the biographical subject's life "right" and rather use the biographical subject in order to project their own vision of life and the world (I will develop this idea in much greater detail in Chapter 5). Given the nature and extent of the liberties these creative writers take with the biographical subject, we could say that Lukács was right to analyze the genre through the lens of fiction rather than biography. The unfortunate trend among many scholars of biofiction, however, is that, when they define the genre, they rarely, if ever, take into account the work of Lukács.

The years 1996 (Benjamin's Crossing) and 1997 ("Fact or Fiction: Writing Biographies Versus Writing Novels") are of crucial importance but in ways that are difficult to document adequately. Within an American context, Parini has probably done more to advance the contemporary biographical novel than any other scholar or writer. ${ }^{63}$ Parini has published poetry, biographies,

${ }^{62}$ Scott (2016), “On Hoaxes, Humbugs, and Fictional Portraiture," a/b: Auto/ Biography Studies, (forthcoming).

"'For a more extensive discussion of Parini's important rok in the making of the American biographical novel, see my "Introduction" to Jay Parini (2014), 
novels, cultural criticism, scholarly essays, and, most importantly, biographical novels. As a friend of Warren, Parini learned much from the Southern writer, but he also had a very close friendship with Vidal, who authored notable biographical novels such as Burr and Lincoln.64 In 1990, Parini published his first biographical novel The Last Station, which is about Leo Tolstoy, and he confesses that Vidal, who read early drafts of the work, gave him many useful suggestions for structuring the multi-perspective narrative. Like Warren, Parini foregrounds history in his novels, but he differs from Warren in that he, like Vidal, names his protagonists after the actual historical figure. In fact, in an interview, Parini claims that Warren's decision to conceal the identity of Huey Long in his novel All the King's Men was a missed opportunity:

In All the King's Men, written in the mid-forties, Robert Penn Warren felt tightly bound to the traditions of conventional historical fiction. I don't think he could see his way toward the contemporary forms of the biographical novel, or else he would have called his protagonist Huey Long, not Willie Stark. I wish he had. I think he could have written a better novel if he'd actually dug into Long, because I know he was obsessed with him. ${ }^{65}$

For Parini, had something been different in Warren's thinking, he would have been able to imagine his way toward the biographical novel.

From the publication of The Last Station in 1990 until today, Parini has committed himself to the biographical novel-he is currently writing one about the apostle Paul. If Parini were an isolated author, we would have to establish textual links between him and other prominent novelists in order to suggest that he helped shape the contemporary American biographical novel. But Parini is the D. E. Axinn Professor of English and Creative Writing

Conversations with Jay Parini. Editor Michael Lackey. Jackson: University Press of Mississippi, ix-xx.

"Parini (1997), "Mentors," in Some Necessary Angels: Essays on Writing and Politics. New York: Columbia University Press, 3-17.

"Parini (2014), "Reflections on Biographical Fiction," in Truthful Fictions: Conversations with American Biographical Novelists. Editor and Interviewer Michael Lackey. London and New York: Bloomsbury, 213. 
at Middlebury College, which is where the famous Bread Loaf Writing Conference is held-many prominent writers have taught at Bread Loaf. Parini has been involved with this conference for decades, and consequently, he has extensive contact with scores of famous writers. To put the matter bluntly, Parini is friends with some of the most prominent writers in the United States, and he has been engaging them in heated debates about and making the case for the biographical novel for decades. Writers who have told me about their experiences with Parini include Banks, author of the 1998 biographical novel Cloudsplitter; Oates, author of the 1999 biographical novel Blonde; and Edmund White, author of the 2007 biographical novel Hotel de Dream. These are three extraordinary biographical novels, and they were all written after the publication of Parini's The Last Station and Benjamin's Crossing (I do an extensive analysis of this novel in Chapter 3) as well as his essay "Fact or Fiction: Writing Biographies Versus Writing Novels." Based on these facts, is it possible to say that, if not for Parini, we would not have stellar biographical novels like Cloudsplitter, Blonde, and/or Hotel de Dream? I would not make such a bold declaration, but it is clear that there are strong lines of connection between Parini and some of the best American biographical novelists.

The contribution of Parini's that I want to underscore has more to do with artitude than content. One of the major stumbling blocks for biographical novelists has been managing and negotiating the competing and sometimes contradictory demands of biography and fiction, a problem that bedeviled Woolf. In her book Victoriana, which examines biographical novels about Henry James, Cora Kaplan, like Woolf, suggests that reconciling the two acts is not possible: "The 'bio' in biofiction also references a more essentialised and embodied element of identity, a subject less than transcendent but more than merely discourse. It implies that there is something stubbornly insoluble in what separates the two genres and that prevents them from being invisibly sutured; the join will always show." ${ }^{\text {} 66}$ Parini would contest this claim, not because he has discovered a way to magically blend the acts of representing (biography) and creating (fiction), but because he subordinates

Kaplan (2007), Victoriand: Histories. Fictions. Criticism. New York: Columbia Universiry Press, 65. 
biographical representation to the writer's vision. Here is how he puts the matter in his 1997 essay about biofiction:

Novels are about lives, after all: about pieces of lives or whole lives. Traditionally, these lives have been made up, with halfbelievable disclosures at the outset that read, "The characters in this novel are entirely fictitious and any relation to persons living or dead is entirely accidental." I would prefer that novelists of the future write: "Everything in the following pages is authentic, which is to say it is as true as I could make it. Take it or leave it. ${ }^{\text {"67 }}$

In the traditional disclaimer, authors made a statement disavowing or qualifying the relationship between the invented character and the real person. But in Parini's version of the disclaimer, the whole idea of the relationship disappears. All readers are left with is the creative writer's vision. In essence, Parini unapologetically asserts his authority as a novelist. What we get in a biographical novel, then, is the novelist's vision of life and the world, and not an accurate representation of an actual person's life. Put differently, biographical novelists differ from biographers, because, while authors of traditional and fictional biographies seek to represent the life (or a dimension of a life) of an actual historical figure as clearly and accurately as possible, biographical novelists use the biographical subject in order to project their own vision of life and the world. Here is how Banks puts the matter: "I'm using history in order to tell a story." 68 The goal is not to do biography. Rather, it is to use history and biography in order to construct a narrative:

My real purpose is to generate and tell a story. It is not to correct history or write an addendum to the historical or biographical record. It is simply to appropriate the material that history has dropped at my door. ... If history drops it on your doorstep, it's there to be used. ${ }^{69}$

\footnotetext{
"Parini (1997), "Fact or Fiction: Writing Biographies Versus Writing Novels," in Some Necessary Angels: Essays on Writing and Politics. New York: Columbia University Press, 250.

"Banks (2014), 45.

"Tbid.
} 
Thus, Banks says that Cloudsplitter should not be read alongside or compared to biographies, but "should be read as a novel, and the books against which it should be measured are novels." 70 Accentuating the fact that they are writing novels rather than biographies liberates biographical novelists from the chokehold of biographical representation.

Within an American context, the year 1999 represents a key turning point in favor of the biographical novel. In this year, three novels were nominated for the Pulitzer. Two (Cunningham's The Hours and Banks' Cloudsplitter) were biographical novels, and Cunningham's The Hours won the award. ${ }^{71}$ Cunningham's novel is significant because it addresses the literary establishment directly. The novel features a prominent writer (Richard) who receives an important literary award. For Cunningham's narrator, this prize "means that literature itself ... seems to feel a need for Richard's particular contribution."72 This is a wonderful way of articulating what happened with the Pulitzer committee. It felt a need at this time for the biographical novelist's contribution. After all, so many prominent American writers had published biographical novels by 1999 that it was impossible to ignore them.

Most encouraging, however, is the content of the Pulitzer's jury report, which indicates a shift in the literary establishment's aesthetic expectations and theory of knowledge. For instance, when discussing The Hours, the committee notes that a "fourth character is Woolf herself," which contributes to the novel's "fourperson complexity." ${ }^{73}$ Instead of assuming that a real person as a character would be a liability, as the 1980 Pulizer committee did, the 1999 members recognize that such a literary choice could be a huge asset. What, in part, made this possible was the committee's acceptance of postmodernism. Before 1999, postmodernism was never mentioned in any Pulitzer jury report for fiction. But in the year that The Hours received the Pulitzer, the committee praised Cunningham for presenting "the floating post-modern world and generation that a number of contemporary writers have tackled, but none 80 artfully and movingly. ${ }^{74}$ Rather than strictly demarcating

Tanks $(2014)$, 50.

nCunningham's The Howrs also won the PEN/Faulkner Award.

nCunningham (1998), The Hours. New York: Picador, 64.

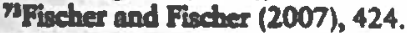

mibid. 
fact and fiction, biography and the novel, or a historical figure and a fictional character, postmodernists suggest that fact is fiction and that fiction is inseparable from fact. This postmodernist shift made the committee understand and appreciate a hybrid aesthetic form such as the biographical novel, which is why we could say that the biographical novel was becoming formally and officially recognized by 1999.

This year is also important because Martin Middeke and Werner Huber published Biofictions, a collection of essays focusing on biographical fictions of people from the Romantic period. ${ }^{75}$ In the introduction, Middeke clarifies how the postmodern Zeitgeist set the stage for the rise of biofiction. Given that "fiction and historiographic/biographical discourse are not mutually exclusive" in a postmodern age, hybrid forms of writing started to emerge. While Middeke acknowledges that the postmodern blending of fact and fiction resulted in hybrid forms of writing, he does not leave matters there, nor does he use this fact as an apologia for an "anything goes" approach to biofiction. Rather, he clarifies how biofiction enables us to formulate a more nuanced conception of a newly understood "factual world." To put the matter succinctly, Middeke claims that the authors of biofictions "may incorporate and reflect upon epistemological uncertainties caused by the aporias of time and language, without obliterating historical consciousness." $\pi 7$ In other words, authors of biofiction do not get rid of the "historical" or "biographical" world. Instead, they provide more complicated ways of understanding the words "historical" and "biographical," and they subsequently use fiction to offer new ways of conceptualizing the historical and biographical. Middeke's introduction signals a decisive move in the right direction for scholars, as it brings rigor

\footnotetext{
${ }^{75}$ It might seem that I should also mention in this context Stephanie Bird's 1998 study Recasting Historical Women: Female Identity in German Biographical Fiction, as this work features biographical fiction in the subtitle. However, Bird's book is primarily about feminism rather than biofiction. And in those rare moments when she discusses the nature of biographical fiction, her terminology is muddled and confusing. Like Schabert, Bird treats biographical fiction and fictional biography as interchangeable. Consequently, she tends to use the criteria of biography rather than fiction to analyze and interpret the works.

"Martin Middeke (1999), "Introduction," in Biofictions: The Rewriting of Romantic Lives in Contemporary Fiction and Drama. Editors Martin Middeke and Werner Huber. Camden: Rochester, 3.

Tbid.
} 
to the conversation, recognizes that biofictions are fictions and not biography, and provides considerable insight into the origin and evolution of the literary form.

The year 1999 was clearly a watershed moment, but the news was not all good. So popular with prominent writers had the biographical novel become that the well-respected American editor and novelist Jonathan Dee published a scathing essay about it in Harpers. According to Dee, "there's no debating that the practice of conscripting flesh-and-blood people into novels has become a veritable epidemic in the last twenty-five years or $50 .{ }^{78}$ Dee considers this an "ominous" sign, as he believes that it represents "a lowering of the literary bar." 80 To be more specific,

Creating a character out of words and making him or her as vivid and memorable as a real person might be is perhaps the hardest of the fundamental tricks a novelist has to perform. Simply adopting or impersonating an already interesting real-life characterLee Harvey Oswald, J. P. Morgan, Amelia Earhart-cannot be considered as substantial an achievement as creating a character who enters the reader's consciousness as a total unknown. ${ }^{\text {s1 }}$

For Dee, the rise of biofiction signifies our age's bankrupt imagination and perhaps the death of fiction.

In 2006, David Lodge published "The Year of Henry James," which tries to explain the mysterious confluence of biographical novels about Henry James in the year 2004. There were three HenryJames-inspired novels in that year, and two were biographical novels, Colm Tóibin's The Master and Lodge's Author, Author. Lodge wonders how it is possible to explain that James never appeared in a fictional work as a protagonist under his own name before Emma Tenant's 2002 novel Felomy, but that in the year 2004, he was the primary subject of Alan Hollinghurst's The Line of Beauty and the protagonist in Tóibín's The Master, Lodge's Author, Author, and Michael Heyns' The Typeuriter's Tale (Heyns' novel was submitted

"Dee (1999). "The Reanimators: On the Art of Literary Graverobbing," Harpers Magazine 298(1789): 77.

Tlbid.

${ }^{\infty}$ Dee (1999), 83-4.

"Dee (1999), 84. 
to publishing houses in 2004 , but because it was the last in the line of James-inspired novels, it was rejected until 2005).

Most fascinating in Lodge's essay is his claim that, even though he has "been reading, teaching and writing criticism about" James since he "was an undergraduate," he could not imagine until recently doing a biographical novel about him, because his "concept of what constituted a novel ... did not include the possibility of writing one about a real historical person. ${ }^{n 2}$ For Lodge, something has changed in the collective consciousness that has made the biographical novel not just possible but also a dominant literary form. Hence his astonishment "that the biographical novel-the novel which takes a real person and their real history as the subject matter for imaginative exploration, using the novel's techniques for representing subjectivity rather than the objective, evidence-based discourse of biography-has become a very fashionable form of literary fiction in the last decade or so." ${ }^{83}$ After wondering "why the biographical novel should have recently attracted so many writers as a literary form," Lodge speculates that its rise "could be taken as a symptom of a declining faith or loss of confidence in the power of purely fictional narrative." ${ }^{84}$ I want to briefly offer an alternative explanation for this intellectual development.

It is my contention that the rise of the biographical novel signaled the decline of what I refer to as the deductive imagination and the emergence of the inductive imagination, which converts a historically specific event into a literary symbol. This was the case because of the rise and legitimization of postmodernism, which, in its most basic form, means "incredulity toward metanarratives." 85 Given the growing skepticism about universals and metanarratives, there was a shift away from aesthetic models that started with an ahistorical precept, the basis for the deductive imagination, and a shift toward models that foregrounded the historically specific, the basis for the inductive imagination. This, I contend, explains why

\footnotetext{
${ }^{2}$ Lodge (2006), 10-11.

"Lodge (2006), 8.

'Lodge (2006), 9-10.

"s Jean.François Lyotard (1991), The Postmodern Condition: A Report on Knowledge.

Translated by Geoff Bennington and Brian Massumi. Minneapolis: University of Minnesota Press, xxiv.
} 
the biographical novel became increasingly more popular with both average readers and prominent writers after the 1970 s.

Developments in Oates' corpus will enable me to best chart the transformation in the literary imagination. In her fiction, Oates viciously criticizes white male liberals, especially the Kennedys and Bill Clinton. For instance, in her biographical novel Blonde, which is about Marilyn Monroe, Oates insightfully pictures the contradictory psychology of prominent American politicians. As a liberal, it would seem that JFK would have a progressive view of women. But in his relationship with Monroe, he is "a patrician patriarch. ${ }^{\text {86 }}$ Oates' JFK, however, is not merely a typical male of the 1960s. He also represents the contradictory psychology of a powerful male liberal of the 1990s. Notice how Oates draws a clear parallel between JFK and Clinton. Monroe enters the president's room while he is on the phone talking to "a White House adviser or cabinet member." ${ }^{87}$ Oates describes what happens in a way that unmistakably recalls the Monica Lewinsky scandal: "Gamely the Blond Actress began to stroke the President's penis, as one might stroke a charming but unruly pet while its owner looked on proudly. Yet, to her annoyance, the President didn't hang up the phone. ${ }^{\text {88 }}$ Published in 1999, this novel was written at the height of the Lewinsky affair. But what is crucial to note is the transformation in Oates' writing during the nineties.

In this decade, Oates clearly targets the contradictory psychology of white male liberals in her fiction. For example, in 1992 Oates authored a work that required readers to use the deductive imagination to critique the American polity. That novella is Black Water, which is like Warren's All the King's Men in that it does not name the protagonist after the original figure. This novella is clearly based on the 1969 Chappaquiddick incident, when Senator Ted Kennedy had a car accident that resulted in the death of Mary Jo Kopechne, who is named Kelly Kelleher in the novella. But instead of naming her character Kennedy, Oates simply refers to him as The Senator. Also, the novel is set in the 1990s, after the first war in Iraq had already started, and the incident occurs on July 4th rather than July 18 th, thus giving it much more political significance. These

${ }^{36}$ Oates (2009), 708

"Oates (2009), 705.

"Ibid. 
changes enable Oates to construct a symbolic character (a universal or metanarrative) that embodies the reckless patriarchal psychology of so many prominent political figures of the 1990s. And once this symbolic character is clearly defined, readers could then use the deductive imagination to illuminate the behavior of a wide range of powerful American males.

By 1999 , with the publication of Blonde, Oates produced fiction that requires readers to use the inductive rather than the deductive imagination-Oates names her protagonist Marilyn Monroe. Through extensive research and expert artistic representation, Oates uses a historically specific example (the Monroe/JFK affair) to construct a literary symbol. That historical specificity functions as an argument confirming Oates' critique of the patriarchy. This is not the work of the fictive imagination, which can easily concoct a sexist character (the Senator as a literary symbol embodying a patriarchal mindset) that could be used to critique powerful males in the real world. In the postmodern age, we are more skeptical of such fictional abstractions because they resemble ahistorical precepts or traditional metanarratives. What we see in Blonde, therefore, is an empirical portrait of a known philanderer, whose reprehensible behavior contributed to the death of an actual woman. But Oates' concern is not just the patriarchal politics of the 1960 s. By subtly using details from the Lewinsky case to describe JFK's treatment of Monroe, Oates invites readers to use the inductive imagination to draw a clear link between the patriarchal politics of JFK and Clinton. What JFK did in the 1960s, Clinton continued to do in the 1990 s. Or, read the other way, we could use the records from the Lewinsky case in order to illuminate what occurred between Monroe and JFK. My point is this: the rise of the postmodern incredulity toward metanarrative necessitated a more empirically rooted and historically specific literary symbol, which, in part, explains the rise and legitimization of biofiction, an aesthetic form that requires readers to use the inductive rather than the deductive imagination in order to understand the author's social, political, and cultural critique. With regard to Oates' fiction, Blonde is a much more compelling critique of white male liberals than Oates' Black Water, because she avoids the charge of using the fictive imagination to concoct a sexist character (traditional literary symbol) that functions like an ahistorical Truth. By naming names and fictionalizing factual figures, Oates produces a searing 
portrait that is much more difficult to dismiss as the product of a paranoid or a runaway imagination. And by inviting readers to use the inductive imagination to link the white male liberals of the 1960s and the 1990s, Oates makes her implicit argument and cultural critique both persuasive and relevant. The shift from the deductive to the inductive imagination not only makes logical sense, but it is also a necessary aesthetic move in a postmodern age for contemporary writers who want to continue in their role as the culture's most insightful social critics.

We are now in a position to offer an alternative way of thinking about the emergence of biofiction. Lodge interprets its rise as a "declining faith or loss of confidence in the power of purely fictional narrative." But for many biographical novelists, given crucial developments in postmodernism, Lodge's belief in pure fiction is naïve and incoherent. To understand why, it is important to take into account the collapse of the fact/fiction binary. In the nineteenth century, when history became an institutionalized discipline that conceived of itself as a science, it distanced itself from literature by expanding and hardening the dichotomy between fact and fiction. Within this framework, historical fact became more dogmatically factual while imaginative fiction became more fantastically fictional. ${ }^{\text {99 }}$

Postmodernists reversed this process, which we see most clearly in my interview with Cunningham about The Hours. Challenging the "questionable faith in the accuracy of history as written," Cunningham rejects the idea of something like categorical "fact," because "we're subjective, by nature." As such, the human subjective always plays a role in the formation of fact, thus rendering fact more subjective and fictional than many previously thought or were willing to admit. It is worth noting that Cunningham is not solely interested in shattering the idea of hardcore fact. Given the embedded nature of the human condition, he also exposes the

\footnotetext{
"For a more detailed analysis of the history of history, see Hayden White's Metalistory: The Historical Imagimation in Nineteenth-Century Europe; George G. lggers' Historiography in the Twentieth Century, and Beverley Southgate's History Meess Fiction.

"Cunningham (2014), "The Biographical Novel and the Complexity of Postmodem Interion," Truthful Fictions: Conversations with American Biographical Novelists. Editor and Interviewer Michael Lackey. London and New York: Bloomsbury, 89.
} 
notion of pure fiction as incoherent nonsense. When discussing the construction of a fictional character, Cunningham says: "I don't see a particularly clear or easily-drawn line between fact and fiction." "1 This is the case because "fiction writers work from" their experience of the world and the people who inhabit it." ${ }^{\mathrm{m92}}$ Some writers, Cunningham continues, seek "to disguise that which" they have "seen and heard." But the reality is that "fiction can only arise out of what a writer has seen and heard." To be more specific: "The mother in a novel may be more like the writer's actual mother, or less like her, but she pretty much inevitably comes from the writer's relationship with a mother. ${ }^{n 93}$

This postmodern approach clearly poses a challenge to Dee's and Lodge's view that the rise of the biographical novel indicates a growing disbelief in pure fiction, because the collapsing borders between fact and fiction ultimately render the idea of pure fiction incoherent. So while Joseph Conrad's Kurtz in Heart of Darkness, F. Scott Fitzgerald's Daisy in The Great Gatsby, and Virginia Woolf's Mr. Ramsay in To the Lighthouse appear to be pure fictional creations, we in the postmodern era know that Kurtz is based on Leon Rom, that Daisy is based on Ginevra King, and that Mr. Ramsay is based on Leslie Stephen. ${ }^{94}$ Disguising the figures by giving them different names produces the illusion that authors have invented purely fictional characters. But the postmodern reality is that these seemingly pure inventions are empirically rooted and historically based. Thus, when it comes to the construction of a fictional character, the major difference between Cunningham's creation of Virginia Woolf and Woolf's creation of Mr. Ramsay is that Cunningham named his character after the actual figure, while Woolf concealed the identity of the person on which the character is based by changing the name. In essence, biographical novelists are simply more transparent than most novelists in that

\footnotetext{
${ }^{91}$ Cunningham (2014), 90.

"Ibid.

${ }^{93}$ Ibid.

"For a discussion of Rom as the basis for Kurtz, see Adam Hochschild's King Leopold's Ghost: A Story of Greed, Terror, and Heroism in Colonial Africa, 140-9. For a discussion of King as the basis for Daisy. see James L. W. West's The Perfect Hour: The Romance of F. Scott Fitzgerald and Gineura King, His First Love. For a discussion of Stephen as the basis for Mr. Ramsay, see my essay "Modernist AntiPhilosophicalism and Virginia Woolf's Critique of Philosophy."
} 
they reveal the source of their characters by naming them after the actual historical figures.

While I have been trying to provide a definitional framework for the biographical novel in this introductory chapter, it would be a mistake to think that there is a Platonic form that can capture the essence of all biographical novels. A better way to think about the genre is in terms of a steady progression in the form's evolution, which we see most clearly through the biographical novels about Eliza Lynch, an Irish woman who was the companion of Francisco Solano López, president of Paraguay from 1862 until 1870. William E. Barrett authored the first biographical novel (Woman on Horseback) about Lynch in 1938, and in his foreword, Barrett insists that his work is faithful to the historical record: "In the preparation of 'Woman on Horseback,' I discarded many romantic legends which would have delighted a novelist and which would have outraged fact. In the writing, I have been faithful to time and place and sequence; in no case distorting the true chronology of events for dramatic effect." 95 Taking liberties with the established facts in his biographical novel is not an option for Barrett. But by the year 2002, Anne Enright has a much different epistemological orientation toward her subject matter. As she says in the acknowledgments to her biographical novel The Pleasure of Eliza Lynch: "Eliza Lynch seems to provoke in her English-speaking biographers all kinds of sneering excess. Some facts seem to remain constant and it is around these facts that this (scarcely less fictional) account has been built. This is a novel, however. It is Not True. ${ }^{96}$ Facts, for Enright, partake of the fictional, which is why her novel is "scarcely less fictional" than the seemingly factual studies on which The Pleasure of Eliza Lynch is based. This is a postmodern move that Barrett's approach precludes. But more importantly, Enright feels free to assert her rights as a creative writer, to use the life of Lynch in order to create a "novel" that "is Not True." Lily Tuck makes a similar claim in her Eliza Lynch novel The News from Paraguay. In her "Author's Notes," Tuck claims that she "tried to keep to historical facts where" she found "them to be important and necessary." But given that many events that occurred "are complicated and, for the most part,

'Barrett (1938), Woman on Horseback: The Biography of Francisco Lopez and Eliza Lynch. New York: Frederick A. Stokes Company, viii.

Enright (2003), The Pleasure of Eliza Lymch. London: Vintage Books, 231. 
not well known," Tuck unapologetically invents. This leads her to make the following disclaimer: "What then, the reader may wonder, is fact and what is fiction? My general rule of thumb is whatever seems most improbable is probably true." To bring into sharp focus the philosophy undergirding her approach, Tuck quotes a friend of hers: "Nouns always trump adjectives, and in the phrase 'historical fiction' it is important to remember which of the two words is which. ${ }^{n 97}$ The noun signifies what an object is, so if we call a work a "fictional biography," then we are talking about a biography. But as Tuck insists, what she writes is fiction. Problematic, of course, is that Tuck refers to her book as historical rather than biographical fiction. But if we attend to Lukács' definitions of the historical and the biographical novel and the evolution of the biographical novel over the last eighty years, then it would make more sense to call The News from Paraguay a biographical rather than a historical novel.

We can now say with confidence that the biographical novel has officially arrived. Consider, for instance, the stellar writers who have authored such works in just the last thirty years: Bruce Duffy, Jay Parini, Joanna Scott, J. M. Coetzee, Margaret Atwood, Julia Alvarez, Thomas Pynchon, Michael Cunningham, Russell Banks, Joyce Carol Oates, Colm Tóibín, Anne Enright, Lance Olsen, Emma Donoghue, Jerome Charyn, Colum McCann, Laurent Binet, and Hilary Mantel. However, despite the stunning output from such notable writers, we still struggle to understand why this aesthetic form came into being, what exactly it is, and how it uniquely pictures the historical and engages the political. Therefore, in the following pages, I provide some answers to these questions. In Chapter 2, I do a contrastive analysis of Ray Monk's Ludwig Wittgenstein: The Duty of Genius and Duffy's The World As I Found It in order to clarify how the traditional biographer and the biographical novelist engage their subject in radically different ways. In Chapter 3, I do an analysis of Parini's Benjamin's Crossing and Olsen's Nietzsche's Kisses in order to show how a rejection of positivism (historical, philosophical, psychological, and scientific) and the rise of surrealism necessitated a new form of the historical novel, which is the biographical novel. In Chapter 4, I illustrate how two of Hurston's biographical novels function to critique the

Thuck (2005), The News from Paraguay. New York: Perennial, 247. 
contemporary political situation in ways more profound than other political novels. In Chapter 5, 1 examine three biographical novels about slavery that expose the sociopolitical structures of oppression from both the past and the present. In the final chapter, $I$ address the ethics of the biographical novel, and I develop a preliminary and provisional model for defining ethical and unethical usages of an actual figure's life.

It should be noted, however, that what 1 do in this book is not to be considered exhaustive. The contemporary biographical novel is one of the richest and most promising aesthetic innovations of the last fifty years, and we are still trying to come to terms with its uncanny power to simultaneously picture the past and the present and to critique the political. Contemporary writers have only started to harness the power of this aesthetic form, and it will take scholars years before they will be able to clearly document and assess the genre's value and importance in giving us an accurate picture of ourselves and advancing the democratic promise of social justice. My objective with this study has been to initiate a more focused conversation. 